\title{
Ibilgailu elektriko, hibrido eta erregai-piladunak: teknologiaren egoera
}

\author{
(Electric, Hybrid and Fuel-Cell Vehicles: \\ State of Technology)
}

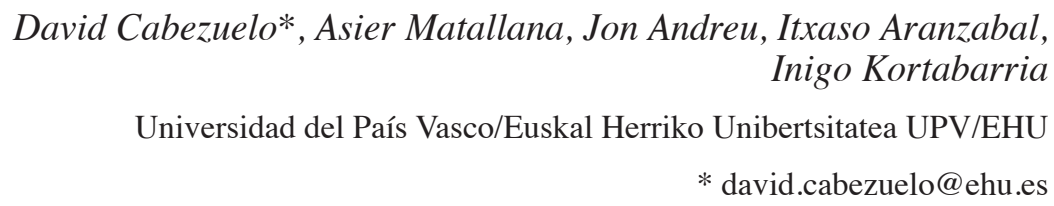

DOI: 10.1387/ekaia.17055

Jasoa: 2016-02-17

Onartua: 2016-06-27

Laburpena: Ibilgailu elektriko, hibrido eta erregai-piladunek duten entzutea geroz eta handiagoa izaten ari da. I+G esfortzuak konfigurazio berri, moldagarri, fidagarriagoetan eta kostu txikiagokoetan zentratzen ari dira. Artikulu honetan, topologia hauetako teknologiaren egoera aurkezten da, sistema berri eta etorkizun handikoetan enfasia jarriz.

Hitz-gakoak: ibilgailuen topologiak; IE; IHE; BIE; EPIE; CSIM; MCM; potentziaelektronika.

\begin{abstract}
The popularity of electric, hybrid and fuel-cell vehicles has not stopped growing. The investment in $\mathrm{R} \& \mathrm{D}$ has been focused on the development of new and more flexible configurations, and more reliable and less expensive systems. This article presents the state of technology of these topologies, emphasizing on new systems with the greater pro jection.
\end{abstract}

Keywords: vehicle topologies; EV; HEV; BEV; FCEV; CSIM; MCM; power electronics.

\section{SARRERA}

Gas-emisio eta kontsumo energetikozko arautegiak geroz eta neurri murriztatzaileagoak dituenez, eta kontzientzia sozialak geroz eta inplikatuagoa dagoenez ingurumena babesteko beharrean, baterietara konektatutako ibilgailu elektrikoak (BIE) (Battery Electric Vehicle, BEV), hibridoak 
David Cabezuelo, Asier Matallana, Jon Andreu, Itxaso Aranzabal, Inigo Kortabarria

(IHE) (Hybrid Electric Vehicle, HEV) eta erregai-piladunak (EPIE) (Fuel Cell Electric Vehicle, FCEV) geroz eta gehiago ari dira automobilgintza, politika eta sektore sozialen atentzioa erakartzen. XX. mendean zehar barne-errekuntzako motorrak (BEM) gailenak izan badira ere, ibilgailuen elektrifikazioa errealitate bat da gaur egun [1].

Teknologia hauen garrantziak eta garapen konstantea dela eta, artikulu honetan ibilgailu elektrikoaren (IE) (Electric Vehicle, EV) teknologiaren egoera azalduko da, topologia ezberdinak aztertuz eta etorkizun handia aurkezten duten berrikuntzetan enfasi berezia jarriz. Alde batetik IHEan [2-8] gehien erabiltzen diren 5 konfigurazioak ikusiko dira CSIM (CompoundStructure Integrated Machine) berrikuntzarekin batera, baita posible diren hibridazio mailak eta hauen hobekuntzak ere [9]. BIEei dagokienez [4-6, 10], konfigurazio zentralizatu eta banandu erabilienak aztertuko dira MCM (Modular Cascale Machines) sistema berriarekin batera. Eta azkenik, EPIEen bi konfigurazio nagusiak ikusiko dira, PEM pilen erabilera orokorraren arrazoiekin batera (2. irudia eta 1. taula) $[4,6,11,12]$.

1. taula. Hibridazio mailaren araberako ibilgailu komertzialak.

\begin{tabular}{lcl}
\hline \multicolumn{1}{c}{ Klasifikazioa } & Hibridazio maila & \multicolumn{1}{c}{ Modeloak } \\
\hline Konbentzionala & $0 \%$ & $\begin{array}{l}\text { Volvo V40 } \\
\text { Audi A3 }\end{array}$ \\
\hline Micro Hybrid & $<10 \%$ & $\begin{array}{l}\text { Citroen C3 Stop\&Start } \\
\text { VW Passat BlueMotion }\end{array}$ \\
\hline Mild Hybrid & $<25 \%$ & $\begin{array}{l}\text { Honda Civic } \\
\text { Honda Insight }\end{array}$ \\
\hline Full Hybrid & $25-50 \%$ & $\begin{array}{l}\text { Toyota Prius } \\
\text { Toyota Highlander }\end{array}$ \\
\hline IHEE & $>50 \%$ & $\begin{array}{l}\text { Toyota Prius PHEV } \\
\text { Honda Accord Plug-in }\end{array}$ \\
\hline AHIE & $>50 \%$ & $\begin{array}{l}\text { Chevrolet Volt } \\
\text { BMV i3 REX }\end{array}$ \\
\hline BIE & $100 \%$ & $\begin{array}{l}\text { VW e-Golf } \\
\text { Nissan e-NV200 }\end{array}$ \\
\hline EPIE & $100 \%$ & $\begin{array}{l}\text { Hyundai ix35 FC } \\
\text { Toyota Mirai }\end{array}$ \\
\hline
\end{tabular}




\section{IBILGAILU KONBENTZIONALA}

Ibilgailu konbentzionaletan Otto zikloa eta Diesel zikloa dira gehien erabiltzen diren BEM desberdinak. Biak aldi berean hobetuz joan dira, baina ziklo termodinamikoa dela eta (Carnot-en limitea) [5], Diesel zikloa efizienteagoa izan da betidanik [13].

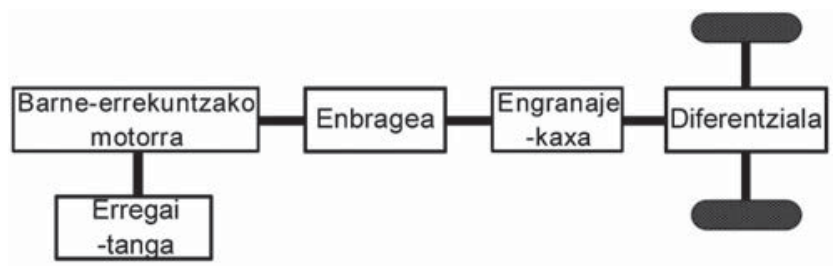

1. irudia. Ibilgailu konbentzional baten konfigurazio generikoa.

Otto zikloko motor perfektu baten efizientzia teorikoa (8:1 konpresioerlazioa duena) \% 56.5ekoa da, eta Dieselaren kasuan (18:1 konpresio-erlazioa duena) \% 63.2koa; baina badira, halaber, BEMen efizientziari eragiten dioten bestelako galerak (hozte-sistema, kargaren berriztapena, etab). Hauek direla eta, BEMen batez besteko efizientzia \% 25ekoa da Otto ziklodunen artean, eta \% 30ekoa, Diesel ziklodunetan, efizientzia horiek puntu optimokoak direla kontuan izanik.

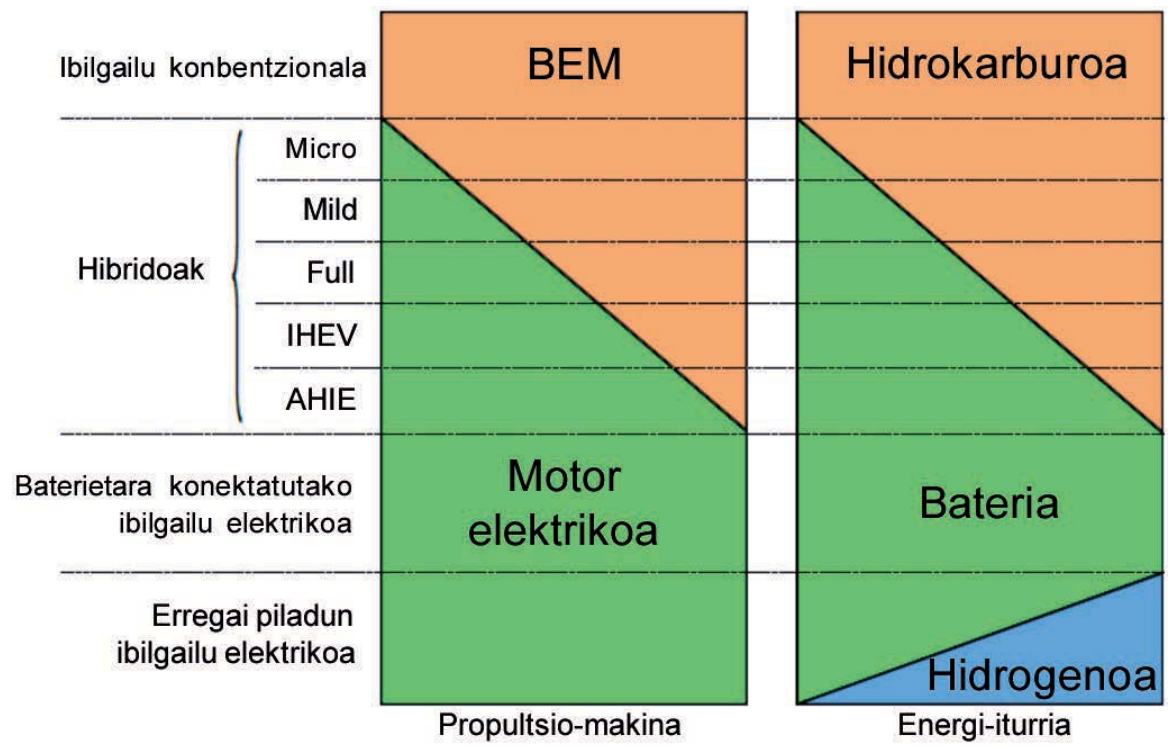

2. irudia. Propultsio sistemen sailkapena. 
David Cabezuelo, Asier Matallana, Jon Andreu, Itxaso Aranzabal, Inigo Kortabarria

Ibilgailu hauen konfigurazioa trakzio-motor eta engranaje-kaxan oinarritzen da. Erregaia tangan metatzen da eta enbrage eta diferentziala transmisio-sistemaren parte dira (1. eta 2. irudiak, eta 1. taula).

\section{IBILGAILU HIBRIDOA}

IHEak motor termiko eta elektrikoen arteko baturan sinergiak lortzeko garatu ziren: autonomia eta potentzia-dentsitatea, batetik, eta eraginkortasuna eta motorraren indarpare abiadura txikietan, bestetik. Honela, efizientzia handiagoa eta ingurumenaren gaineko inpaktu txikiagoa duen sistema bat sortzen da. Zentzu honetan, IHEen helburu nagusia da BEMa efizientzia maximoko puntutik hurbil ahal den denbora tarte luzeenean lan eginaraztea [5].

2. taula. HEV konfiguraziodun ibilgailu komertzialak.

\begin{tabular}{llccc}
\hline \multicolumn{1}{c}{ Konfigurazioa } & \multicolumn{1}{c}{ Modeloa } & Urtea & $\begin{array}{c}\text { Potentzia totala } \\
(\mathrm{kW})\end{array}$ & $\begin{array}{c}\text { Autonomia totala } \\
(\mathrm{km})\end{array}$ \\
\hline Seriea & Opel Ampera & 2012 & 111 & 500 \\
Paraleloa & Honda Insight & 2009 & 101 & 1.150 \\
Seriezko-Paraleloa & BYD F3DM & 2008 & 126 & 430 \\
Complex & Cadillac Escalade & 2008 & 282 & - \\
TtR & Peugeot 3008 & 2012 & 149 & 1.500 \\
\hline
\end{tabular}

\subsection{Konfigurazio hibridoak}

Duela urte gutxi arte, IHEtzak bi oinarrizko konfigurazio zeuden: seriea eta paraleloa. Baina azken urteotan, erregaiaren ekonomia eta energi errendimendua hobetzeko asmoz, beste konfigurazio batzuk garatu izan dira (3. irudia eta 2. taula) [2, 6]:

1. Serie konfigurazioa: BEMa sorgailu batera konektatuta dago; honek bateriak kargatu edota motor elektrikoa elika dezake, azkenengoa izanda ibilgailua trakzionatzen duena. Modu honetan, BEMak errendimendu maximoko puntuan lan egin dezake une oro. Abiadura-kaxarik eta bestelako osagai mekanikorik ez duenez behar, ibilgailuaren mekanikan sinpletasun handioagoa lortzen da. Konfigurazio oso efizientea bada ere, behar adina kapazitate duen bateria baten beharrak sistema honen erabilera mugatzen du [5]. Arkitektura honek 6 funtzionamendu modu ditu [6], eta sistema hau darabilten autoei Autonomi Hedatutako Ibilgailu Elektrikoak (AHIE) deritze [3]. 

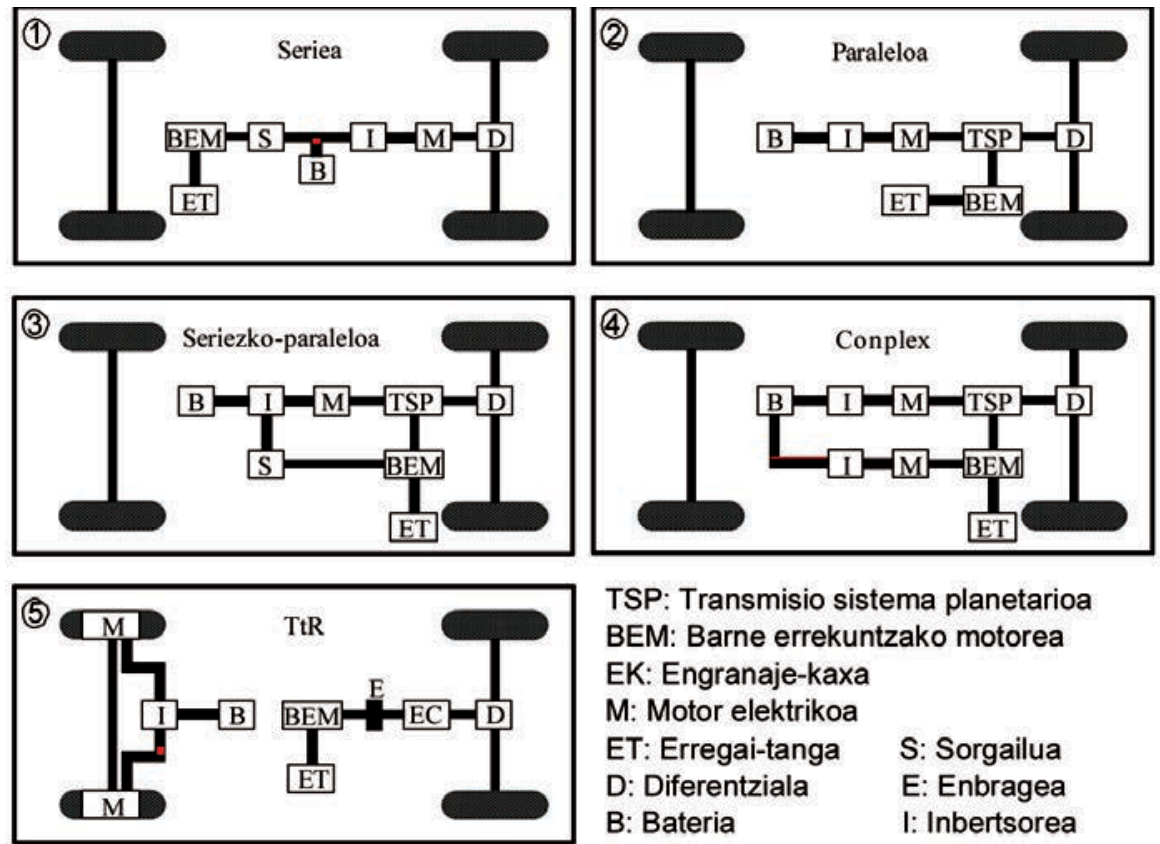

TSP: Transmisio sistema planetarioa BEM: Barne errekuntzako motorea EK: Engranaje-kaxa M: Motor elektrikoa ET: Erregai-tanga S: Sorgailua D: Diferentziala E: Enbragea B: Bateria I: Inbertsorea

3. irudia. Ibilgailu hibridoen konfigurazioak.

2. Paralelo konfigurazioa: funtsean, trakzio elektrikoa erabiltzen du BEMaren efizientzia energetikoa hobetzeko, BEMa efizientzia altuko biraketa-abiadurako erregimenetan bakarrik lan eginaraziz. Ibilgailuak bi transmisio sistemetako edozein (edo biak batera) erabili dezake. Baina trakzio elektrikoa gidatze-kondizioak aldatzean erabiltzen da oro har: hasierarazterakoan, energa birsortzeko, eta BEMaren potentzia soberakinak xurgatzeko [5]. Serie konfigurazioarekin konparatuta, baterien kargarako sorgailurik ez du behar, eta txikiagoak diren bi motorekin sistemaren errendimendu bera lortu daiteke [6]. Bestalde, transmisio sistema planetario baten beharrak konplexuagoa bihurtzen du. Honek ere 6 funtzionamendu modu desberdin ditu [6].

3. Seriezko-paralelo konfigurazioa: aurreko konfigurazioen ezaugarriak batzen ditu. Hala ere, arkitektura hau nahiko konplexu, garesti eta kontrolatzeko zaila da. Bestalde, fabrikazioko teknologia eta kontroleko aurrerakuntzei esker, IHE moderno batzuek nahiago dute sistema hau [6].

4. Conplex konfigurazioa: seriezko-paralelo konfigurazioaren antzekoa da hau. Kasu honetan BEMera lotuta dagoen motor elektrikoak sorgailu moduan lan egin dezakeenez, energi fluxua bi noranzkoa da. Eta honi esker beste hiru propultsio modu lor daitezke $[5,6]$. 
David Cabezuelo, Asier Matallana, Jon Andreu, Itxaso Aranzabal, Inigo Kortabarria

5. Through the Road (TtR): Hybrid4 ere esaten zaio, lau gurpileko trakzioa duen konfigurazio paraleloa da. BEMak bi ardatzetako bat trakzionatzen duen bitartean, bestea motor elektrikoak trakzionazen du [11]. Bi propultsio-sistemen artean ez dago konexio mekanikorik, hauen arteko lotura gurpilen eta errepidearen bitartez egiten da. Horrela, engranaje-sistema asko sinplifikatzen da conplex konfigurazioaren aldean, eta, bestalde, ibilgailu konbentzional baten hibridazioa asko errazten da [7,11]. Energi fluxuen arabera, 5 modu desberdinetan lan egin dezake [7].

6. Compound-Structure Integrated Machines (CSIMs): transmisio elektromagnetikozko konfigurazio berri honek bi makina elektriko integratzen ditu sistema berean [11]. Bi konexio elektriko eta bi ardatz mekaniko dituen estatore-makina (EM) batez eta errotore bikoitzeko beste makina (EBM) batez dago osatuta (4. irudia). Beste konfigurazioekin konparatuta, CSIM sistema askoz konpaktuagoa eta arinagoa da.

Gaur egun teknologi hau ez dago oso garatuta, baina azken urteotan ikerketa asko egin dira CSIM sistemaren topologi eta konfigurazioen inguruan [11]. Horien artean indukzio motor, iman iraunkorrezko makina sinkrono, SRM (Switching Reluctance Machine ) [8] eta kontrol estrategien inguruko ikerketak aurki daitezke.

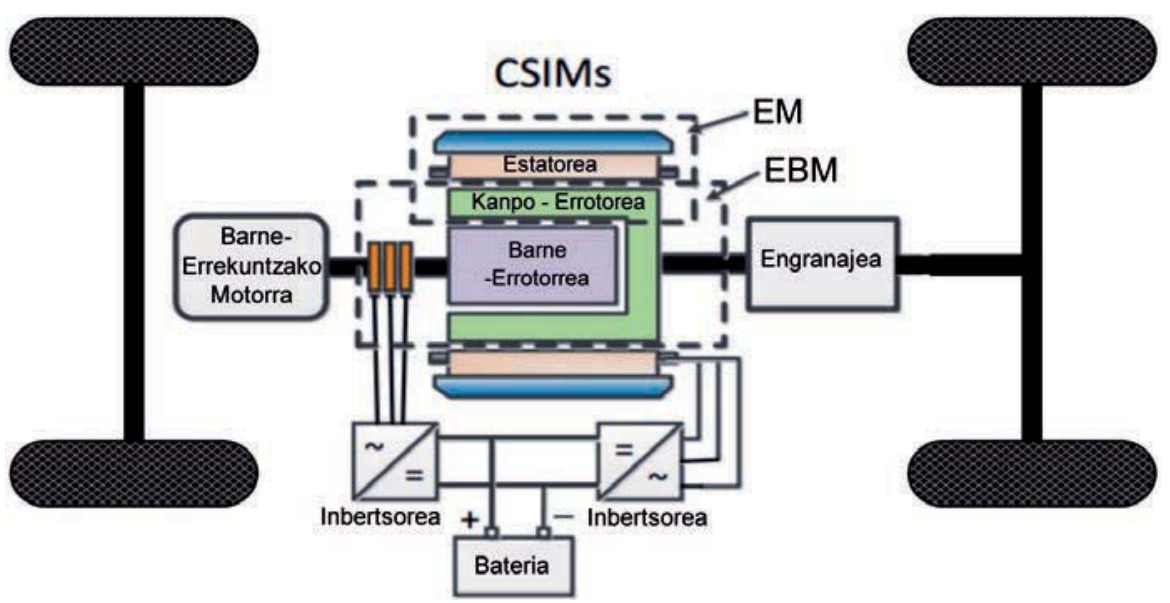

4. irudia. CSIM sistemadun ibilgailu hibridoaren eskema.

Hauek dira gaur egun gehien erabiltzen diren konfigurazioak, eta garatzen ari direnen artean nabarmenenak. 


\subsection{Hibridazio mailak}

Bestalde, IHE konfigurazioek BEM eta motor elektrikoaren arteko potentzi ratioaren arabera sailkatu daitezke, guztiz hibridoa den ibilgailura arte 3 maila daudela (3. eta 4. taulak, eta 2 . irudia) $[6,15]$ :

3. taula. IHE konfigurazioen klasifikazioa.

\begin{tabular}{lccccc}
\hline \multicolumn{1}{c}{ Topologia } & Micro HEV & Mild HEV & Full HEV & IHEE & AHIE \\
\hline Seriea & & & $\mathrm{x}$ & $\mathrm{x}$ & $\mathrm{x}$ \\
Paraleloa & $\mathrm{x}$ & $\mathrm{x}$ & $\mathrm{x}$ & & \\
Seriezko-paraleloa & & & $\mathrm{x}$ & $\mathrm{x}$ & \\
Complex & & $\mathrm{x}$ & $\mathrm{x}$ & \\
Through the Road & & $\mathrm{x}$ & $\mathrm{x}$ & \\
CSIM & & $\mathrm{x}$ & $\mathrm{x}$ & \\
\hline
\end{tabular}

a) Micro hybrid : abio-motor klasikoa ISG (Integrated Starter-Generator ) sistema batez ordezkatzen da. Honek motor termikoa itzali eta pizten du ibilgailuaren geldiunetan (Start/Stop system), hiriguneetan erregai-kontsumoa aurreztuz. ISGak sorgailu moduan ere lan egin dezake (funtzio mugatua) dezelerazio- eta balaztatze-guneetan bateria kargatzeko.

b) Mild Hybrid : BEMaren eta transmisioaren artean motor elektriko bat kokatzen da kasu honetan. Adibidez, inertzia-bolantea ordezka dezan, diametro handiko plaka biribilaren formarekin diseina daiteke. Era honetan, propultsioan laguntzeaz gain, Start/Stop eta balazta birsortzailearen funtzioak zuzkitzen ditu.

c) Full hybrid : motor elektrikoaren potentziari eta baterien kapazitate handiagoari esker (konfigurazioaren araberakoak), Full Hybrid-ak modu elektriko puruan lan egin dezakete. Potentzi banaketa ahalbideratzeko, CVT (Continuosly Variable Transmission) sistema edota beste mota batekoak erabili ditzakete. Ibilgailu hibridoen abantaila guztiak zuzkitzen ditu.

Ibilgailu hauek beste bi motetan sailka daitezke: Synergy Hybrid eta Power Hybrid. Lehenengoek efizientzia energetikora eta gas-emisioaren murrizketara bideratzen dira. Bigarrenen kasuan, potentzi errendimenduaren hobekuntzan zentratzen dira.

Hibridazio maila bakoitzaren inplementazioak gainbalio bat izango du. Micro Hybrid-ek aurrezpen energetiko eta gainbalio txikia erakusten dute, Full Hybrid-ek, aldiz, aurrezpen energetiko eta gainbalio handienak, eta Mild Hybrid-ak bien arteko konpromisoa (5. irudia). Dena den, hauetariko bakoitzak bere merkatu-hobia du (2. irudia eta 1. taula). 
David Cabezuelo, Asier Matallana, Jon Andreu, Itxaso Aranzabal, Inigo Kortabarria

Full Hybrid klasikoak ezin du modu elektriko batean denbora luzez lan egin, baterien kapazitateak autonomia asko mugatzen baitu. Gaur egun, entxufatu daitekeen aldaera bat eta bateriak BEMaren bitartez kargatzen dituen beste aldaera bat aurki daitezke $[2,5,6,15]$ :

4. taula. Hibridazio maila desberdinen ezaugarriak.

\begin{tabular}{lcccc}
\hline \multicolumn{1}{c}{ Mota } & $\begin{array}{c}\text { Start/Stop } \\
\text { Sistema }\end{array}$ & $\begin{array}{c}\text { Balazta } \\
\text { Birsortzailea }\end{array}$ & IE era & Berriz Kargatu \\
\hline Micro hybrid & Bai & Bai & Ez & Ez \\
Mild hybrid & Bai & Bai & Ez & Ez \\
Full hybrid & Bai & Bai & Bai & Bai \\
IHEE & Bai & Bai & Bai & Bai \\
AHIE & Bai & Bai & Bai & \\
\hline
\end{tabular}

d) IHEE (Ibilgailu Hibrido Elektriko Entxufagarria) (Plug-in Hybrid Electric Vehicle, PHEV): Full Hybrid-en onura guztiak dituzte, baina bateriak saretik karga daitezke. Autonomia hobetzeko, baterien kapazitatea handitzen da (5 kWh-etik gora), $8.8 \mathrm{kWh}-\mathrm{ko}$ 2015 eko Prius-a adibidez. Horrela, modu elektriko (charge-depleting mode) edo modu mistoan (blended mode) lan egin dezakete. Ibilgailu hauen efizientzia energetikoa oso handia izan daiteke, eta ibiltarte laburretan (hirietan adibidez) gas-emisiorik eduki gabe.

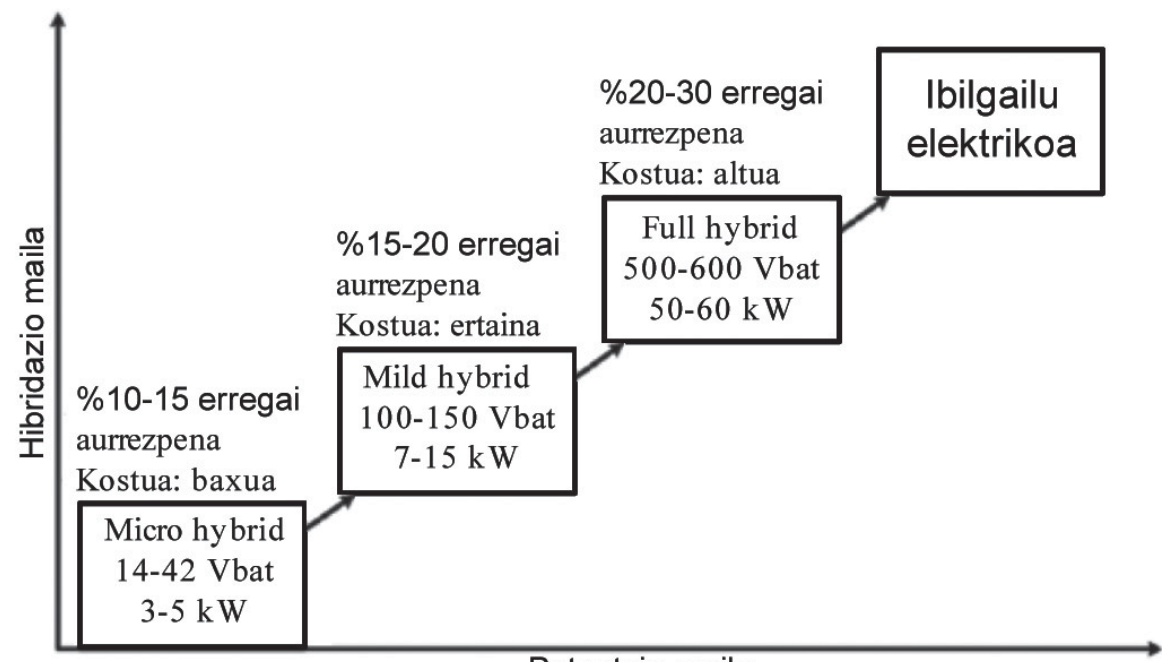

Potentzia maila

5. irudia. Hibridazio mailen, gainkostuen eta potentzien konparazioak. 
e) AHIE (Autonomi Hedatutako Ibilgailu Elektrikoa) (Extender Range Electric Vehicle, EREV): IHEEen eta serie-konfigurazioaren abantailak batzen ditu. Modu elektrikoan ibiltzen dira denbora guztian zehar, eta BEMaren eginkizun bakarra bateriak kargaraztea da honen autonomia handitzeko. IHEEarekin konparatuz BEM txikiagoa bat dute baterien kapazitatea handitzeko [3] (16 kWh-tik gora), 22 kWh-ko BMW i3-a eta 18 kWh-ko Chevrolet Volt-a adibidez.

Laburbilduz, ibilgailu baten hibridazio maila handitzen den heinean erregai kontsumoa gutxituz doaz; eta Full Hybrid mailara iristerakoan, bateria saretik birkargatzeko (IHEE) sistema batekin, edo bateriak BEM baten bitartez kargatzeko (AHIE) sistemarekin hobetu daiteke (1. taula).

\section{BATERIETARA KONEKTATUTAKO IBILGAILU ELEKTRIKOAK}

BIEak motor elektrikoz bakarrik trakzionatzen diren ibilgailuak dira, eta bateriak dira energi iturri bakarra (2. irudia eta 1. taula). Bateria hauek saretik kargatzen badira ere [9], badaude gaur egun eguzki-energiaz kargatzen direnak teknologia hau integratuz (SEV, Solar Electric Vehicle) $[3,10]$.

BIEetan erabiltzen diren konfigurazioak bi multzotan sailka daitezke: zentralizatuak (motor bakarra) eta bananduak (multimakina). Zentralizatuak, erabilitako lehenengoak (konbentzionaletan oinarritzen dira) eta gaur egunera arte erabilienak izan dira. Baina oso moldagarriak ez direnez, azkenengo urteotan multimakinen inguruko ikerketak asko ugaritu dira [11], hauen moldagarritasunarengatik eta funtzionamendu modu gehiagotan lan egin dezaketelako batez ere.

Gaur egun gehien erabiltzen diren konfigurazioak (6. irudia) $[3,5,11]$ :

a) 1. konfigurazioa: motor elektriko, enbrage, engranaje-kaxa eta diferentzial batez osatuta dago. Enbragea, engranaje-kaxarekin batera, gidariari martxak aldatzea ahalbidetzen dio (abiadura/indar-pare erlazioa). Konfigurazio hau erabiliena izan da ibilgailu konbentzionala eraldatzeko errazena delako.

b) 2. konfigurazioa: lehenengoaren sinplifikazioa, engranaje-kaxa engranaje finko batez ordezkatuz enbragea ez da beharrezkoa. Aldaketa hauek posible dira motor elektrikoek abiadura-tarte handi baten zehar potentzi konstantea emateko ahalmena dutelako.

c) 3. konfigurazioa: aurreko trakziodun ibilgailu konbentzional baten antzerakoa da. Motor elektrikoa, engranaje finkoa eta diferentziala gurpilen ardatzean jartzen dira zuzenean, potentzia-trena asko sinplifikatuz. 
David Cabezuelo, Asier Matallana, Jon Andreu, Itxaso Aranzabal, Inigo Kortabarria
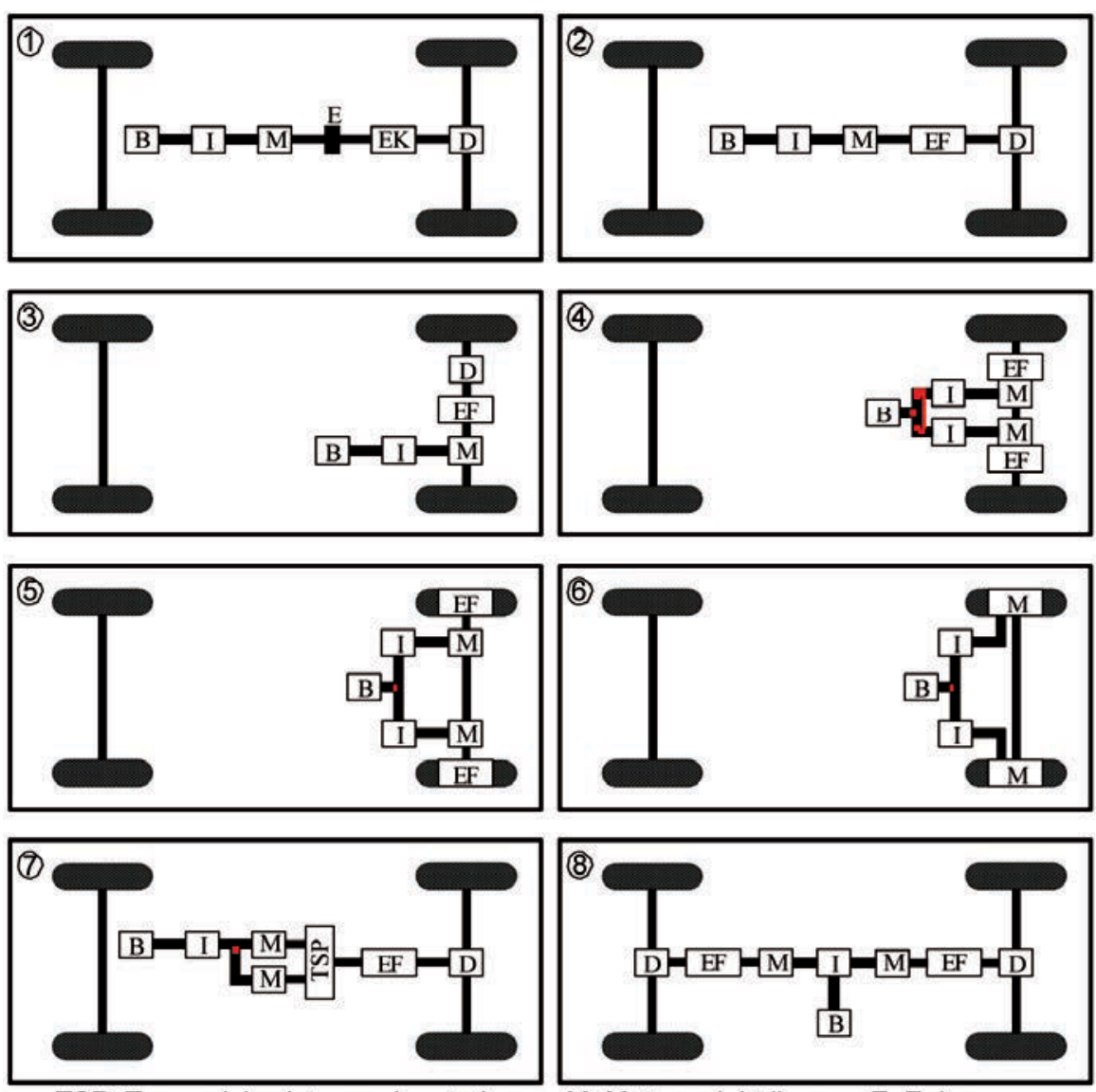

TSP: Transmisio sistema planetarioa

EK: Engranaje kaxa

EF: Engranaje finkoa

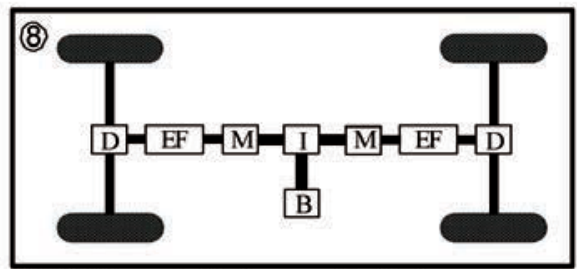
M: Motore elektrikoa
B: Bateria
E: Enbragea
I: Inbertsorea
D: Diferentziala

6. irudia. Baterietara konektatutako ibilgailuen konfigurazioa.

d) 4. konfigurazioa: diferentzialaren eginkizuna modu elektroniko batean ere egin daiteke, bi motorrekin abiadura desberdinetan lan eginez. Kasu honetan, ardatzeko gurpil bakoitza motor eta engranaje finko baten bitartez trakzionatzen da.

e) 5. konfigurazioa: transmisio mekanikoa laburtzeko, motor elektrikoa gurpilaren ondoan kokatzen da, honi In-Wheel Drive deritzo. Motor eta gurpilaren artean, abiadura txikitu eta indar-parea handitzen duen engranaje finko bat jartzen da.

f) 6. konfigurazioa: transmisio mekanikoa guztiz sinplifikatzeko, motor elektrikoa gurpilean bertan kokatu daiteke engranaje finkorik 
gabe, honela transmisio-efizientzia optimo bat lortuz eta sistemaren egitura asko txikituz. Bestalde, abiadura txikietan indar-pare handia eman dezakeen motor elektriko bat behar da, azelerazio on bat edukitzeko.

g) 7. konfigurazioa: trakzio zentralizatu honetan, bi motor elektriko erabiltzen dira transmisio planetariozko sistema batetik lotuta [11]. Motorretako bat abiadura handietarako diseinatzen da, eta bestea, berriz, indar-pare handia emateko. Honela, abiadura handia lor daiteke indar-pare txikietara eta alderantziz.

h) 8. konfigurazioa: trakzio banandu honetan, ardatz bakoitza indibidualki trakzionatu eta kontrolatzen da. Ondorioz, ibilera dinamikoa, erosotasun handiagoa eta egitura diseinu askoz malguagoa aurkezten du [11]. Gainera, motorrak gehituz ibilgailuaren potentzia eskalatu daiteke, lau gurpiletako In-Wheel Drive sistema batera arte.

Hauetaz gain, efizientzia optimoko area handitzeko, akatsen aurreko tolerantzia hobetzeko eta trakzio-sistemen mantentze-lanak errazteko [11], MCM (Modular Cascade Machines) sistema berri bat ikertzen eta garatzen ari dira [14]. Sistema multimakina honetan motorrak seriean konektatzen dira bateri-pakete baten moduan (7. irudia).

Hauek dira bere ezaugarri aipagarrienak:

1. Motor unitatearen diseinu modularra: $\mathrm{I}+\mathrm{G}$, manufaktura eta mantentze-lanen kostuak murriztuz.

2. Diseinu integrala: IEak behar dituen ezaugarrietara hobeto moldatuz. Adibidez, motor bat indar-pare handia abiadura txikietara emateko, beste bat alderantziz lan egiteko eta hirugarren bat abiaduratarte batean efizientzia handia edukitzeko diseinatu daitezke.

3. Akatsen aurreko tolerantzia: sistema erredundante moduan egiten du lan. Beraz, akatsen bat eduki dezakeen motorra sistematik deskonektatzen da besteei kalterik egin gabe.

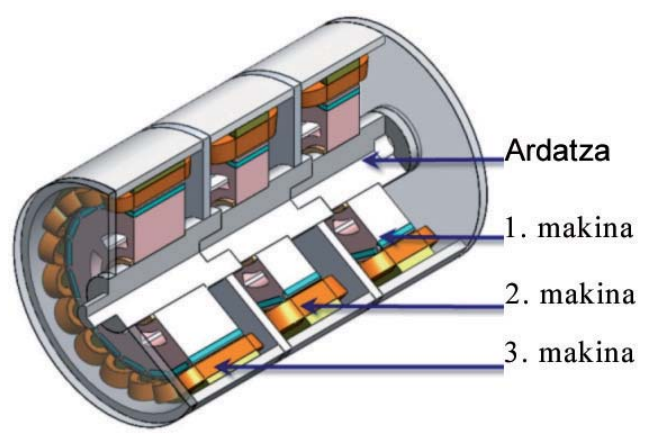

7. irudia. MCM baten egitura. 
David Cabezuelo, Asier Matallana, Jon Andreu, Itxaso Aranzabal, Inigo Kortabarria

Bestalde, planteamendu honek buruhauste asko ditu oraindik: indar-parearen kizkurdura txikitu, potentzi dentsitatea handitu eta makinaren bolumena txikitu; kontrol integratu baten diseinua eta hutsegitetolerantziarako estrategia diseinatu [11, 14]. Hala ere, MCM sistemek izan dezaketen potentzia ikusiz, etorkizun handiko ikerkuntza-bide interesgarri bat dela esan daiteke, IErako multimakina transmisio-sistemen barruan.

\section{ERREGAI-PILADUN IBILGAILU ELEKTRIKOAK}

EPIEtan motorrak behar duen energi elektrikoa erregai-pilen bitartez sortzen da (2. irudia eta 1. taula), soberakinak bateria edo ultra-kapazitateetan metatuz. PEM (Polymer Electrolyte Membrane) erregai-pilak dira gehien erabiltzen direnak, hauek tangatan gordetzen den hidrogenoa eta aireko oxigenoa hartu eta, energi elektrikoa sortzen dute [3]. Energiaren sorkuntzak, prozesu elektrokimiko baten bitartez denez, BEMak baino askoz errendimendu altuagoak lortu dezakete.

PEMek sortzen duten potentzia, hauen tamaina eta zenbatekoen araberakoa izango da. Gainera, energi elektrikoaz gai, PEMek ura eta beroa sortzen dutenez, kogenerazio sistema batekin sistemaren errendimendu totala handitu daiteke $[4,12]$.

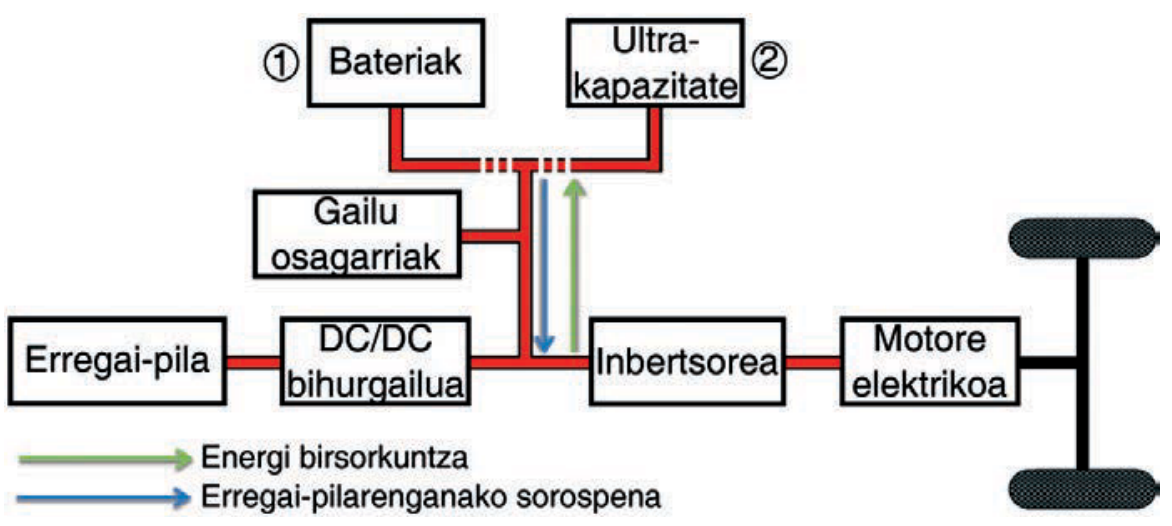

8. irudia. Erregai-piladun ibilgailuen konfigurazioak.

Ibilgailuetan bi modu orokor daude erregai-pila erabiltzeko (8. irudia) [5]:

a) Erregai-piladun ibilgailu elektriko purua: erregai-pila da energi iturri bakarra. Erregai-pilek energia asko eman dezakete erregimen 
konstante batean, baina potentzi pikoen eskaeretara gaizki moldatzen direnez, energiaren erregulazio efiziente bat egiteko ultra-kapazitate multzo bat izaten dute.

b) Erregai-piladun ibilgailu hibridoak: bateriak dira motorra elikatzen dutenak, eta erregai-pilek hauen kargarako erabiltzen dira. Abantaila nagusia baterien autonomian datza, erabiltzaile gehienek egunean $30 \mathrm{~km}$ baino gutxiago egiten dituztenez, baterien kargarekin nahikoa dute eta hidrogenoan erabilera bidaia luzeetan egin dezakete bakarrik [12].

PEMen ordez beste erregai-pila asko erabil daitezke, adibidez: erregai alkalinozkoak, azido fosforikozkoak, karbonatozkoak, SOCak (Solid Oxide Fuel-Cell ). Hala ere, 100C-tik beherako abio erraza, tamaina txikietan duen potentzi dentsitatea, egitura eta erregai-metatze sinplea, eta bibrazio/talken aurreko sendotasuna dela eta, PEMa da automobilgintzan gehien erabiltzen den teknologia.

Bestalde, teknologia honek arazo batzuk dakartza: metal preziatuzko katalizatzaileen beharra, erregaiak eduki dezakeen $\mathrm{CO}$ kontzentrazioa $10 \mathrm{ppm}$-tik behera egon beharra, etab. Honek guztiak sistema asko garestitzen du $[4,12]$.

\section{ONDORIOAK}

Egindako ikerketaren emaitza moduan, EVaren teknologiak ibilgailu konbentzionala modu gradual batean ordezkatzeko nahiko aurreratuta dagoela ondoriozta daiteke. Ibilgailu konbentzionalak beraien fidagarritasunean eusten ziren orain arte, BEM, IHE eta EPIE-ak askoz konplexuagoak direnez (azpisistema askoz osatuta egoten dira) fidagarritasun txikiagoa izaten zuten eta. Hala ere, arkitektura berrien enpleguak konfigurazio hauen murrizketak partzialki edo guztiz ezabatzen ditu, akatsen aurreko tolerantzia hobetuz.

CSIM konfigurazio hibridoak, garapen asko falta bazaio ere, abantaila oso interesgarriak aurkezten ditu (sistema trinko eta arina) eta ikerkuntza asko sorrarazi du. Bestalde, MCM multimakina sistema berriak diseinu modularra (makina desberdinen ezaugarriak batuz) eta akats-tolerantzia handia eskaintzen du. Bi planteamendu hauek oraindik konpondu beharreko arazo asko dituzte, baina etorkizun handiko bi konfigurazio garrantzitsu bezala aurkezten dira. 
David Cabezuelo, Asier Matallana, Jon Andreu, Itxaso Aranzabal, Inigo Kortabarria

\section{ESKER ONAK}

Argitalpen honetan deskribatzen den lana PIU11/16 Prestakuntza eta Ikerkuntzarako Unitate barruan burutu da, UPV/EHUn eta Eusko Jaurlaritzako Hezkuntza, Unibertsitate eta Ikerketa Sailaren bitartez finantziatuta: euskal unibertsitateen ikerkuntza-taldeak bultzatzeko IT394-10 laguntzaren bitartez, eta ELKARTEK (KK-2015/00047) programaren KT4TRANS ikerkuntza-proiektuaren bitartez. Baita Ekonomia eta Lehiakortasun Ministerioaren bitartez ere DPI2014-53685-C2-2-R ikerkuntza-proiektuaren eta FEDER fondoei esker. Eta baita UPV/EHUn Ikertzaileak prestatzeko kontratazio laguntzei ere (2015).

\section{BIBLIOGRAFIA}

[1] INTERNATIONAL ENERGY AGENCY (IEA). 2016. Gloval EV Outlook 2016. OECD, France.

[2] C. CHAN, A. BOUSCAYROL eta K. CHEN. 2010. «Electric, hybrid, and fuel-cell vehicles: Architectures and modeling». Vehicular Technology, 59, 589-598.

[3] C. MAHMOUDI, A. FLASH eta L. SBITTA. 2014. «An overview of electric vehicle concept and power management strategies». International Conference on Electrical Sciences and Technologies in Maghreb, 1-8.

[4] A. EMADI, Y.J. LEE eta K. RAJASHEKARA. 2008. «Power electronics and motor drives in electric, hybrid electric, and plug-in hybrid electric vehicles». Acoustic Speech and Signal Processing, 55, 2237-2245.

[5] J. ALTZIBAR, E. IBARRA, J. ANDREU, A. MATALLANA eta I. KORTABARRIA. 2014. «Ibilgailu elektrikoak eta hibridoak: efizientzia energetikoa hobetzeko aukera». Ekaia, 113-129.

[6] C. CHAN. 2007. «The state of the art of the electric, hybrid and fuel cell vehicles». Proceedings of the IEEE, 95, 704-718.

[7] S. ZULKIFLI, S. MOHD, N. SAAD eta A. AZIZ. 2015. "Operation, power flow, system architecture and control challenges of split-parallel through-the-road hybrid electric vehicle». 10th Asian Control Conference, $1-6$.

[8] S. CUI, Y. YUAN eta T. WANG. 2008. «Research on switched reluctance doublerotor motor used for hybrid electric vehicle». International Conference on Electrical Machines and Systems, 3393-3396.

[9] A. POZO eta E. MOLERO. 2013. El Vehiculo Electrico y su Infraestructura de Carga. Marcombo.

[10] G. CHANDRA MOULI, PP. BAUER eta M. ZEMAN. 2015. «Comparison of system architecture and converter topology for solar powered electric vehicle charging station». 9th International Conference on Power Electronics and ECCE, 1908-1915. 
[11] S. CUI, S. HAN eta C. CHAN. 2014. «Overview of multi-machine drive systems for electric and hybrid electric vehicles». IEEE Conference and Expo Transportation Electrification Asia-Pacific, 1-6.

[12] M. EHSANI, Y. GAO, S.E. GAY eta A. EMADI. 2005. Hybrid Electric, and Fuel Cell Vehicles, CRC Press.

[13] F. PAYRI eta J.M. DESANTES. 2011. Motores de Combustión Interna Alternativos. Editorial Revert, España.

[14] S. HAN, S. CUI, X. ZHANG, H. GE eta B. XU. 2012. «The modular cascade machines in electric vehicles». IEEE Vehicle Power and Propulsion Conferece, 1-6.

[15] K. CHAU. 2015. Electric Vehicle Machines and Drives: Design, Analysis and Application. Wiley-IEEE Press. 